\title{
Comparative study of physicochemical parameters of groundwater and surface water of Rawatsar, Hanumangarh (Rajasthan)
}

\section{Leela Kaur \& Sonu Bala}

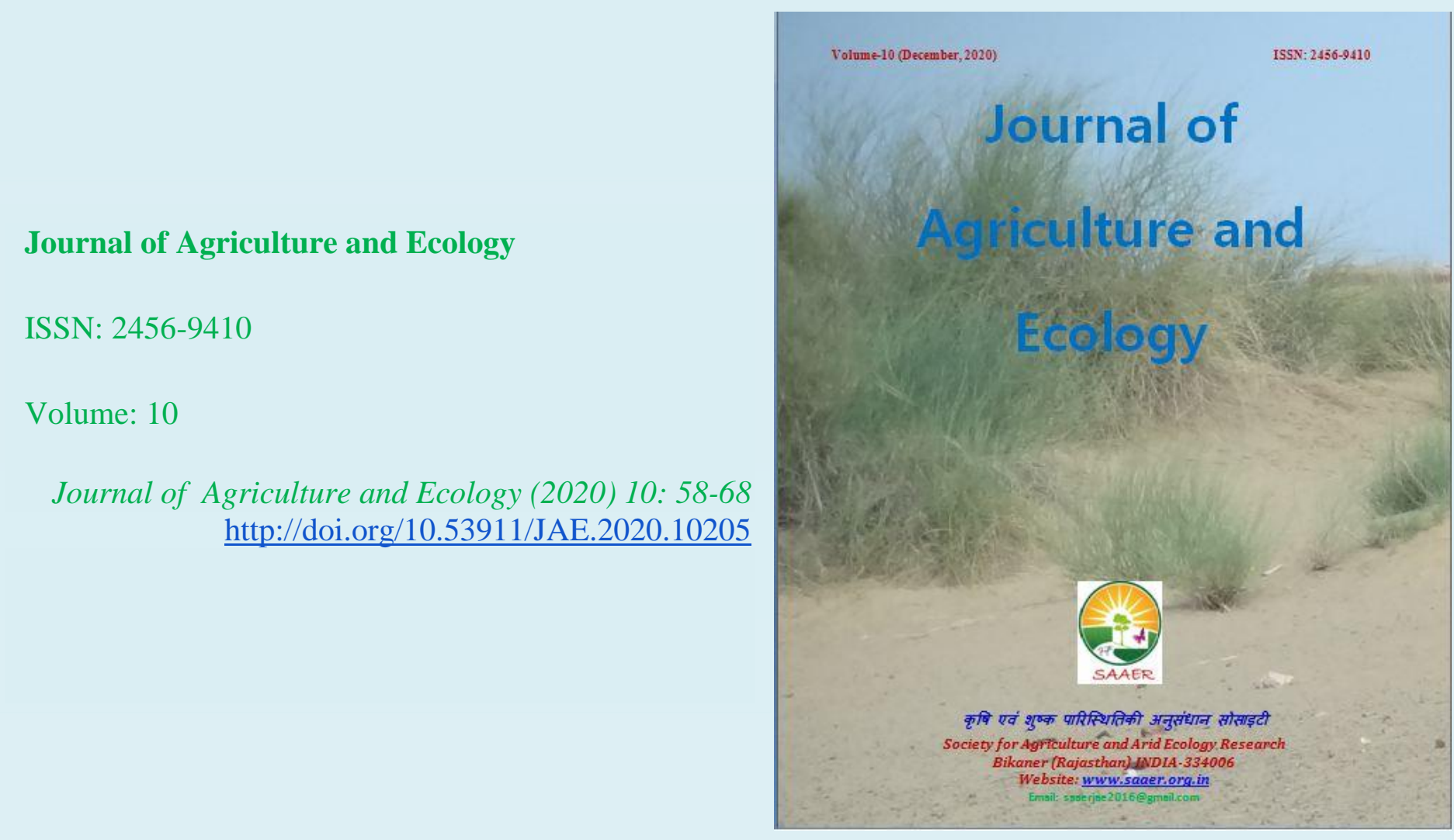




\title{
Comparative study of physicochemical parameters of groundwater and surface water of rawatsar, Hanumangarh (Rajasthan)
}

\author{
Leela Kaur $\searrow \&$ Sonu Bala \\ Department of Environmental Science, Maharaja Ganga Singh University, Bikaner - 334004
}

(Rajasthan), India.

Corresponding author: Leela Kaur, E-mail:Lleela.kaur@gmail.com

Article Info

Article history

Received: 20 October 2020

Accepted: 05 December 2020

Available online: 31 December 2020

Key Words: Surface water, groundwater, water quality parameters, Hanumangarh.

\begin{abstract}
A study on the comparison of surface water and groundwater quality in Rawatsar Tehsil of Hanumangarh district (Rajasthan) was carried out. Different sites were selected for analysis of groundwater and surface water. Physicochemical parameters of water such as $\mathrm{pH}$, EC, TDS, Turbidity, Alkalinity, Chloride, DO, COD, Na and $\mathrm{K}$ were analyzed using standard methods for all the samples. It was found that $\mathrm{pH}$ and $\mathrm{EC}$ were within the BIS permissible limit. All water samples have chloride content more than BIS standard values, showing the dominance of chloride ions in the study area. From the present study, surface water and groundwater samples have higher turbidity and high content of total dissolved solids, alkalinity, chloride, sodium and potassium. Groundwater dominates chloride, carbonate, sodium and potassium ions. Hence, surface water and groundwater need to be treated before end-use. This preliminary study needs to be researched further for a better understanding of hydrogeochemistry of groundwater and chemistry of surface water in Rawatsar.
\end{abstract}

Copyright $(\odot)$ Kaur \& Bala, This is an open access article published under the terms of the Creative Commons Attribution License, which permits unrestricted use, distribution, and reproduction in any medium, provided the original work is properly cited.

Preferred citation: Kaur L \& Bala S. 2020. Comparative study of physicochemical parameters of groundwater and surface water of rawatsar, Hanumangarh (Rajasthan). Journal of Agriculture and Ecology, 10: 58-68; http://doi.org/10.53911/JAE.2020.10205.

\section{Introduction}

Water is the basis of human existence. It is getting contaminated day by day due to anthropogenic activities such as overexploitation of water resources, discharge of chemicals and other wastes, etc. It has become a concerned issue to tackle water contamination. In place of the same, water analysis is essential to check whether the water quality is following standards prescribed by the competent authority. Several studies have been done on analysis of water quality including surface water and groundwater (Choudhary et al. 2007; Gandhi \& Namboodiri 2009; Singh et al. 2009; Mahananda et al. 2010; Sharma 2011; Singh et al. 2013; Asare-Donkor et al. 2016; Kumar et al. 2016; Midha et al. 2016; Lawrence 2017; Tiwari et al. 2017; Toure et al. 2017; Olasoji et al. 2019; Jha et al. 2020; Verma et al. 2020). Indiscriminate exploitation of ground water for agricultural and industrial 
purpose is affecting the quality and quantity of ground water. Ground water quality is getting poor due to excessive dose of iron, manganese, chloride, sulphates, total dissolved solids, hardness, alkalinity or acidity (Sankar et al. 2014). The present study was done in Rawatsar Tehsil of Hanumangarh district (Rajasthan) with the aim of a comparative study of surface water and groundwater quality in the study area.

\section{Materials and Methods}

Study area: The study area is Rawatsar which is located between the latitudes $29^{\circ} 14^{\prime}$ to $29^{\circ} 10^{\prime} \mathrm{N}$ and longitudes $73^{\circ} 48^{\prime}$ to $74^{\circ} 20^{\prime} \mathrm{E}$ in Hanumangarh district of Rajasthan (Figure 1).
Figure 1: Map showing the sampling locations in Rawatsar, Hanumangarh.

Rawatsar falls under the western part of Hanumangarh. It is a municipality city divided into 25 wards. The total population of Rawatsar is 35,102 out of which 18,308 are male and 16,794 are females (Census of India 2011). The study area is irrigated by Rawatsar and Naurangdesar distributaries of Indira Gandhi Canal (IGNP) respectively. The climate of the area is hot and arid with extremes of temperature (average temperature $\left.25.4^{\circ} \mathrm{C}\right)$, erratic and scanty rainfall $(239 \mathrm{~mm}$ annual) and high evapotranspiration (Maurya 2017). Hanumangarh district is an undulating plain covered with a thick layer of windblown sand which forms the part of the Great

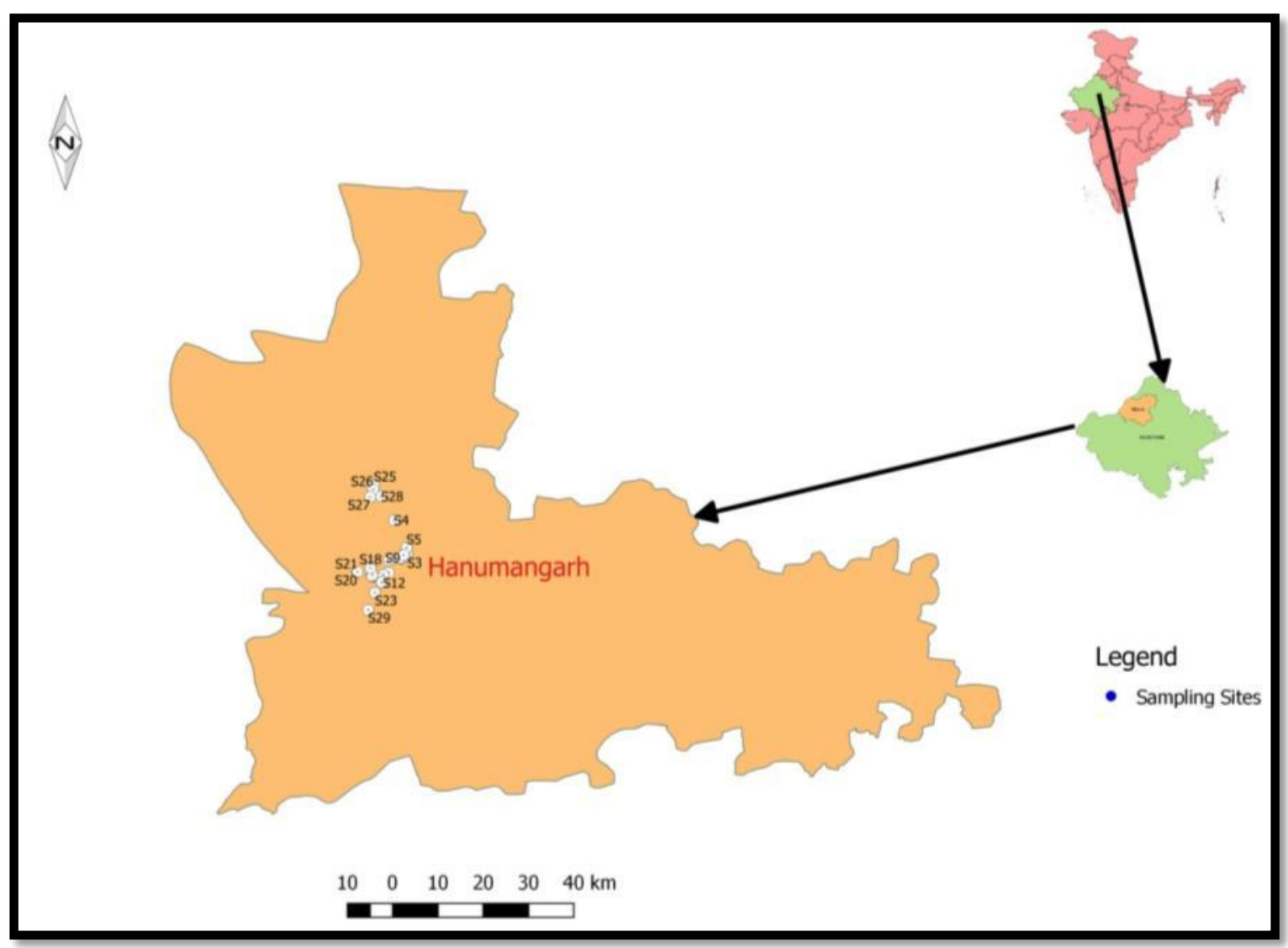


Indian Thar Desert. Northwestern parts of this district have broader plains and southeastern part of this district is comparatively more hilly area. The Ghaggar River is the only major river in the district which is locally known as Ghaggar Naala. Highest elevation of $239 \mathrm{~m}$ found in Rawatsar block. The sand dunes are generally 4 to 5 meters high except in the south western part of Hanumangarh where they are more intensely developed, being sometimes 10 to 15 meters in height (Hydrogeological atlas of Rajasthan Hanumangarh district 2013).

The entire Hanumangarh district is covered by Quaternary Alluvium overlain by thin veneer of wind-blown sand in the central part and by high dunes in the southern Part. In the northern part and in the Ghaggar flood plain, alluvium is without any blown sand cover. Quaternary alluvium is mostly fluvial in origin and consists of alternating sequence of sand, silt and clay. The thickness of alluvium varies from $100 \mathrm{~m}$ in the southern part to over $400 \mathrm{~m}$ in the northern part (Hanumangarh-central ground water board).
The northern part of the district is covered by arid soils which are characterized by alluvial soils. These soils are loamy in character. Central part of the district is characterized by entisols, i.e., desert soils which are loamy along Ghaggar river course. Southern part of the district is characterized by arid soils i.e. non-calcic brown desert (Hanumangarhcentral ground water board). Sample collection: Water sampling was carried out during February to March, 2018 at the selected sampling sites as shown in Table 1. A total of thirty water samples were collected for physico-chemical analyses. Samples included surface water (river, wastewater and pond) and ground water (well and hand pump). Water samples were collected in 1 litre polyethylene bottles. These bottles were previously washed with detergent, rinsed with tap water and then with distilled water and finally rinsed three times with the source water samples. The water samples were carefully labeled and stored in a refrigerator at a temperature between $0^{\circ} \mathrm{C}$ and $4^{\circ} \mathrm{C}$.

Table 1. Selected sampling sites in Rawatsar (Hanumangarh)

\begin{tabular}{lcccc}
\hline Sample code & Latitude & Longitude & Location & Type of water \\
\hline S1 & $29^{\circ} 15.8960^{\prime} \mathrm{N}$ & $074^{\circ} 24.1146^{\prime}$ & Daab & Waste water-SW \\
S2 & $29^{\circ} 15.8831^{\prime} \mathrm{N}$ & $074^{\circ} 24.1298^{\prime}$ & Bawdi shiv mandir & Tube well-GW \\
S3 & $29^{\circ} 15.7596^{\prime} \mathrm{N}$ & $074^{\circ} 24.4247^{\prime}$ & Mishtri market & Hand pump-GW \\
S4 & $29^{\circ} 19.6307^{\prime} \mathrm{N}$ & $074^{\circ} 22.9428^{\prime}$ & IGNP (Lakhuwali & SW \\
& & & head) & \\
S5 & $29^{\circ} 16.5775^{\prime} \mathrm{N}$ & $074^{\circ} 24.3382^{\prime}$ & Near khetarpalji & Drinking water -SW \\
& & & temple & \\
S6 & $29^{\circ} 15.5104^{\prime} \mathrm{N}$ & $074^{\circ} 24.1753^{\prime}$ & New dhanmandi & Hand pump-GW \\
S7 & $29^{\circ} 15.3451^{\prime} \mathrm{N}$ & $074^{\circ} 23.7514^{\prime}$ & Near bahra house & Waste water- SW \\
S8 & $29^{\circ} 15.3508^{\prime} \mathrm{N}$ & $074^{\circ} 23.7659^{\prime}$ & Near main highway & Sam water-SW \\
S9 & $29^{\circ} 15.3989^{\prime} \mathrm{N}$ & $074^{\circ} 23.6398^{\prime}$ & Near main highway & Hand pump-GW
\end{tabular}




\begin{tabular}{|c|c|c|c|c|}
\hline S10 & $29^{\circ} 15.1515^{\prime} \mathrm{N}$ & $074^{\circ} 22.3289^{\prime}$ & Gorkhnathji temple & pond-SW \\
\hline S11 & $29^{\circ} 13.7704^{\prime} \mathrm{N}$ & $074^{\circ} 22.3289^{\prime}$ & 26 DWD & Tube well-GW \\
\hline S12 & $29^{\circ} 13.4990^{\prime} \mathrm{N}$ & $074^{\circ} 21.7075^{\prime}$ & 29 DWD & $\begin{array}{c}\text { Water wax diggiI- } \\
\text { SW }\end{array}$ \\
\hline S13 & $29^{\circ} 13.0711^{\prime} \mathrm{N}$ & $074^{\circ} 21.2690^{\prime}$ & 31 DWD & Tube well-GW \\
\hline S14 & $29^{\circ} 13.3532^{\prime} \mathrm{N}$ & $074^{\circ} 20.5067^{\prime}$ & 30 DWD & Tube well-GW \\
\hline S15 & $29^{\circ} 13.3620^{\prime} \mathrm{N}$ & $074^{\circ} 20.3605^{\prime}$ & 30 DWD & Hand pump-GW \\
\hline S16 & $29^{\circ} 13.3605^{\prime} \mathrm{N}$ & $074^{\circ} 20.3599^{\prime}$ & 30 DWD & Tube well-GW \\
\hline S17 & $29^{\circ} 13.4898^{\prime} \mathrm{N}$ & $074^{\circ} 20.5062^{\prime}$ & 30 DWD & Tube well-GW \\
\hline S18 & $29^{\circ} 14.3626^{\prime} \mathrm{N}$ & $074^{\circ} 20.2903^{\prime}$ & $16 \mathrm{KWD}$ & Joda-SW \\
\hline S19 & $29^{\circ} 14.2803^{\prime} \mathrm{N}$ & $074^{\circ} 20.2748^{\prime}$ & $16 \mathrm{KWD}$ & Tap water \\
\hline S20 & $29^{\circ} 13.8058^{\prime} \mathrm{N}$ & $074^{\circ} 18.7954^{\prime}$ & Khodan & Sahwa lift canal-SW \\
\hline S21 & $29^{\circ} 13.8429^{\prime} \mathrm{N}$ & $074^{\circ} 18.8414^{\prime}$ & Khodan & Hand pump-GW \\
\hline S22 & $29^{\circ} 15.7292^{\prime} \mathrm{N}$ & $074^{\circ} 23.9955^{\prime}$ & Rawatsar & Tap water \\
\hline S23 & $29^{\circ} 11.5275^{\prime} \mathrm{N}$ & $074^{\circ} 20.7809^{\prime}$ & Dhannasar & Tube well-GW \\
\hline S24 & $29^{\circ} 12.6785^{\prime} \mathrm{N}$ & $074^{\circ} 21.5509^{\prime}$ & Param industry & tube well-GW \\
\hline S25 & $29^{\circ} 23.6206^{\prime} \mathrm{N}$ & $074^{\circ} 20.6733^{\prime}$ & Mainawali & Hand pump-GW \\
\hline S26 & $29^{\circ} 23.1066^{\prime} \mathrm{N}$ & $074^{\circ} 20.6058^{\prime}$ & Mainawali & Hand pump-GW \\
\hline S27 & $29^{\circ} 22.2548^{\prime} \mathrm{N}$ & $074^{\circ} 20.2495^{\prime}$ & Mainawali & $\begin{array}{l}\text { Rain water-Tap } \\
\text { water }\end{array}$ \\
\hline S28 & $29^{\circ} 22.2972^{\prime} \mathrm{N}$ & $074^{\circ} 21.4785^{\prime}$ & Mainawali & Hand pump-GW \\
\hline S29 & $29^{\circ} 09.5754^{\prime} \mathrm{N}$ & $074^{\circ} 20.0244^{\prime}$ & Aapniyojna & $\begin{array}{l}\text { Water supply diggi- } \\
\text { SW }\end{array}$ \\
\hline S30 & $29^{\circ} 12.6785^{\prime} \mathrm{N}$ & $074^{\circ} 21.5509^{\prime}$ & Param industry & Tap water \\
\hline
\end{tabular}

Physicochemical water analysis:

Physicochemical parameters of water such as pH, EC, TDS, Turbidity, Alkalinity, Chloride, DO, COD, Na and $\mathrm{K}$ were analyzed for all the samples. All physicochemical water parameters were estimated by standard methods (Maiti, 2011). pH, electric conductivity (EC) and Total Dissolved Solids (TDS) were measured by using the water analyzer kit (Model Systronics 371). Turbidity was measured by Naphalometer. Alkalinity and chloride was measured by titration methods. Chloride was estimated by Mohr's Argentrometric method using phenolphthalein and methyl orange indicators. Dissolved
Oxygen (DO) was measured by the Azide modification of Winkler Method while Biological Oxygen Demand (BOD) and Chemical Oxygen Demand (COD) were estimated using incubation followed by titration and open reflux method respectively. However, sodium $(\mathrm{Na})$ and potassium $(\mathrm{K})$ were analyzed by flame photometer.

\section{Results and Discussions}

Physicochemical parameters of surface water and ground water in Rawatsar (Hanumangarh) were analyzed and obtained results are given in Table 2 to 4 . Tables 5 to 7 represent the range of surface water, ground water and tap water of the study area 
respectively. Table 8 shows the Bureau of 1991).

Indian Standard for drinking water (BIS,

Table 2. Physicochemical surface water quality of Rawatsar village

\begin{tabular}{llcccccccccc}
\hline S.N. & $\begin{array}{l}\text { Sample } \\
\text { Code }\end{array}$ & pH & EC & TDS & Turbidity & Alkalinity & Cl & DO & COD & Na & K \\
\hline 1 & S1 & 6.2 & 11.9 & 6330 & 1.8 & 168 & 30,530 & 0.2 & 66 & 250 & 8 \\
2 & S4 & 6.9 & 0.37 & 259 & 0.3 & 238 & 71 & 6.4 & 27.6 & 3.5 & 0.3 \\
3 & S5 & 6.8 & 0.23 & 161 & 0.1 & 72 & 78.1 & 5.9 & 98 & 4 & 1 \\
4 & S7 & 6.8 & 2.2 & 1540 & 4.6 & 288 & 3053 & 0.1 & 163.2 & 255 & 8.5 \\
5 & S8 & 6.6 & 1.8 & 1260 & 3.5 & 358 & 2556 & 0 & 72 & 270 & 9 \\
6 & S10 & 7.0 & 0.37 & 259 & 0.7 & 40 & 2627 & 5.5 & 58 & 25 & 7.5 \\
7 & S12 & 7.09 & 0.27 & 189 & 0.7 & 66 & 2343 & 5.6 & 52 & 22 & 1 \\
8 & S18 & 6.6 & 0.54 & 378 & 2.8 & 204 & 1988 & 2.2 & 50 & 150 & 6 \\
9 & S20 & 6.4 & 0.31 & 217 & 4.6 & 150 & 191.7 & 6.2 & 28.6 & 1.35 & 0.3 \\
10 & S29 & 4.3 & 0.3 & 217 & 2.3 & 90 & 252 & 5.5 & 72 & 150 & 7.8 \\
\hline
\end{tabular}

All parameters are in $\mathrm{mg} / \mathrm{l}$ except $\mathrm{pH}, \mathrm{EC}(\mu \mathrm{S} / \mathrm{cm})$ and turbidity (NTU).

Table 3. Physicochemical ground water quality of the Rawatsar

\begin{tabular}{lllllllllll}
\hline S.No & $\begin{array}{l}\text { Sample } \\
\text { Code }\end{array}$ & pH & EC & TDS & Turbidity & Alkalinity & Cl & COD & Na & K \\
\hline 1 & S2 & 7 & 5.8 & 4050 & 0 & 190 & 6816 & 24 & 5 & 0.2 \\
2 & S3 & 6.6 & 8.6 & 6020 & 2 & 162 & 10579 & 57.6 & 365 & 8.5 \\
3 & S6 & 6.3 & 9.4 & 6580 & 0 & 246 & 9585 & 113.2 & 295 & 7.5 \\
4 & S9 & 6.3 & 16.9 & 11830 & 4.2 & 180 & 24140 & 200 & 345 & 7 \\
5 & S11 & 7.4 & 1.3 & 910 & 0 & 286 & 2130 & 52 & 300 & 6 \\
6 & S13 & 7.1 & 9.8 & 6860 & 0 & 244 & 13277 & 92 & 250 & 8.5 \\
7 & S14 & 7.4 & 5.2 & 3640 & 0 & 344 & 6035 & 82 & 200 & 7 \\
8 & S15 & 7.8 & 2.4 & 1820 & 2.3 & 316 & 3053 & 80 & 211 & 9 \\
9 & S16 & 7.2 & 6.5 & 4550 & 0 & 550 & 6248 & 81 & 252 & 8.5 \\
10 & S17 & 6.9 & 2.3 & 1610 & 0.2 & 316 & 2840 & 83 & 199 & 8.3 \\
11 & S21 & 7.3 & 0.83 & 581 & 0.4 & 598 & 134.9 & 72 & 310 & 10 \\
12 & S23 & 7.6 & 6.2 & 4340 & 0.1 & 640 & 8875 & 79.6 & 275 & 7.5 \\
13 & S24 & 7.3 & 8.8 & 6160 & 0 & 560 & 10153 & 65 & 171 & 6.9 \\
14 & S25 & 7.1 & 3.8 & 2660 & 0 & 232 & 3905 & 75.1 & 310 & 9.5 \\
15 & S26 & 7.2 & 0.75 & 525 & 4.8 & 308 & 2627 & 80 & 315 & 7.9 \\
16 & S28 & 7.01 & 2.2 & 1540 & 0.7 & 300 & 2840 & 72 & 150 & 7.8 \\
\hline
\end{tabular}

All parameters are in $\mathrm{mg} / \mathrm{l}$ except $\mathrm{pH}, \mathrm{EC}(\mu \mathrm{S} / \mathrm{cm})$ and turbidity (NTU). 
Table 4. Physicochemical Tap water quality of the Rawatsar

\begin{tabular}{llccccccccc}
\hline $\begin{array}{l}\text { S. } \\
\text { No. }\end{array}$ & $\begin{array}{l}\text { Sample } \\
\text { code }\end{array}$ & pH & EC & TDS & Turbidity & Alkalinity & Cl & COD & Na & K \\
\hline 1 & S19 & 6.7 & 0.31 & 217 & 0 & 144 & 1917 & 30 & 5 & 0.45 \\
2 & S22 & 7.5 & 0.36 & 252 & 0.3 & 188 & 159.75 & 27.4 & 1.35 & 0.35 \\
3 & S27 & 6.93 & 0.31 & 217 & 0.2 & 114 & 127.8 & 28.3 & 1.35 & 1 \\
4 & S30 & 6.3 & 0.28 & 196 & 1.6 & 130 & 3408 & 28.5 & 2.5 & 1.5 \\
\hline
\end{tabular}

All parameters are in $\mathrm{mg} / \mathrm{l}$ except $\mathrm{pH}, \mathrm{EC}(\mu \mathrm{S} / \mathrm{cm})$ and turbidity (NTU).

Table 5. Physico-chemical parameters of surface water samples with their analyzed range in Rawatsar (Hanumangarh)

\begin{tabular}{lccc}
\hline Parameters & Range & Minimum & Maximum \\
\hline $\mathrm{pH}$ & $4.3-7.09$ & S29 (Aapni yojna diggi) & S12 (29 DWD) \\
EC & $0.23-11.9 \mu \mathrm{S} / \mathrm{cm}$ & S5 (Near khetarpalji temple) & S1 (Daab) \\
TDS & $161-8330 \mathrm{mg} / \mathrm{l}$ & S5 (Near khetarpalji temple) & S1 (Daab) \\
Turbidity & $0.1-4.6 \mathrm{NTU}$ & S5 (Near khetarpalji temple) & S7 (Near bahra house) \\
Alkalinity & $40-358 \mathrm{mg} / \mathrm{l}$ & S10 (Gorkhnathjimandir) & S8 (Sam water) \\
$\mathrm{Cl}$ & $71-30,530 \mathrm{mg} / 1$ & S4 (IGNP CANAL) & S1 (Daab) \\
DO & $0-6.4 \mathrm{mg} / 1$ & S8 (Sam water) & S4 (IGNP CANAL) \\
COD & $27.6-163.2 \mathrm{mg} / 1$ & S4 (IGNP CANAL) & S7 (Near bahra house) \\
Na & $1.35-270 \mathrm{mg} / \mathrm{l}$ & S20 (Sahwalift canal, khodan) & S8 (Sam water) \\
K & $0.31-9 \mathrm{mg} / 1$ & S4 (IGNP CANAL) & S8 (Sam water)
\end{tabular}

Table 6. Physico-chemical parameters of ground water samples with their analyzed range in Rawatsar (Hanumangarh)

\begin{tabular}{|c|c|c|c|}
\hline Parameter & Range & Minimum & Maximum \\
\hline $\mathrm{pH}$ & $6.3-7.8$ & S6 (New dhanmandi) & S15 (30 DWD) \\
\hline $\mathrm{EC}$ & $0.75-16.9 \mu \mathrm{S} / \mathrm{cm}$ & S26 (mainawali) & S9 (ward no 3) \\
\hline TDS & $525-11830 \mathrm{mg} / \mathrm{l}$ & S26 (mainawali) & S9 (ward no 3) \\
\hline Turbidity & $0-4.8 \mathrm{NTU}$ & $\begin{array}{c}\text { S2, S6, S11, S13, S14,S16, } \\
\text { S19, S24, S25 }\end{array}$ & S26 (mainawali) \\
\hline Alkalinity & $162-640$ mg/l & S3 (Mishtri market) & S23 (Dhannasar) \\
\hline $\mathrm{Cl}$ & $134.9-24140 \mathrm{mg} / \mathrm{l}$ & S21 (khodan) & S9 (ward no 3) \\
\hline COD & $24-200 \mathrm{mg} / \mathrm{l}$ & S2 (Bawdishivmandir) & S9 (ward no 3) \\
\hline $\mathrm{Na}$ & $5-365 \mathrm{mg} / \mathrm{l}$ & S2 (Bawdishivmandir) & S3 (Mishtri market) \\
\hline $\mathrm{K}$ & $0.2-10 \mathrm{mg} / \mathrm{l}$ & S2 (Bawdishivmandir) & S21 (khodan) \\
\hline
\end{tabular}


Table 7. Physico-chemical parameters of Tap water samples with their analyzed range in Rawatsar (Hanumangarh)

\begin{tabular}{lccc}
\hline Parameter & Range & Minimum & Maximum \\
\hline $\mathrm{pH}$ & $6.3-7.5$ & S30 (POP industry) & S22 (Rawatsar ) \\
$\mathrm{EC}$ & $0.28-0.36 \mu \mathrm{S} / \mathrm{cm}$ & S30 (POP industry) & S22 (Rawatsar) \\
TDS & $196-252 \mathrm{mg} / \mathrm{l}$ & S30 (POP industry) & S22 (Rawatsar) \\
Turbidity & $0-1.6 \mathrm{NTU}$ & S19 (16 KWD) & S30 (POP industry) \\
Alkalinity & $114-188 \mathrm{mg} / \mathrm{l}$ & S27 (mainawali) & S22 (Rawatsar) \\
$\mathrm{Cl}$ & $127.8-3408 \mathrm{mg} / 1$ & S27 (mainawali) & S30 (POP industry) \\
$\mathrm{COD}$ & $27.4-30 \mathrm{mg} / \mathrm{l}$ & S22 (Rawatsar) & S19 (16 KWD) \\
$\mathrm{Na}$ & $1.35-5 \mathrm{mg} / \mathrm{l}$ & S22 (Rawatsar) & S19 (16 KWD) \\
$\mathrm{K}$ & $0.35-1.5 \mathrm{mg} / \mathrm{l}$ & S22 (Rawatsar) & S30 (POP industry) \\
\hline
\end{tabular}

Table 8. Physico chemical standard parameters of drinking water by Bureau of Indian standard (BIS: IS 10500, 1991)

\begin{tabular}{lcc}
\hline S. No. & Parameters & Permissible limit \\
\hline 1 & $\mathrm{pH}$ & $6.5-8.5$ \\
2 & EC & $50 \mu \mathrm{S} / \mathrm{cm}$ \\
3 & TDS & $500 \mathrm{mg} / \mathrm{l}$ \\
4 & Turbidity & $1 \mathrm{NTU}$ \\
5 & Alkalinity & $200 \mathrm{mg} / \mathrm{l}$ \\
6 & Chloride & $250 \mathrm{mg} / \mathrm{l}$ \\
7 & D.O. & $4-8 \mathrm{mg} / 1$ \\
8 & COD & $300 \mathrm{mg} / 1$ \\
9 & Na & $180 \mathrm{mg} / \mathrm{l}$ \\
10 & K & $0.2 \mathrm{mg} / \mathrm{l}$ \\
\hline
\end{tabular}

$\mathrm{pH}$ : In the present study area, groundwater has the $\mathrm{pH}$ ranging from 6.3 (New dhan mandi) to 7.8 (30 DWD) which indicates that the water is slightly acidic to normal in nature. Surface water has the $\mathrm{pH}$ ranging from 4.3 (aapni yojna) to 7 (gorkhnath ji temple, mansrowar) which indicates that the water is acidic nature owing possibly due to hydrolysis of carbonates present in water. Most of the brackish waters on other hand show $\mathrm{pH}$ from 7.58 to 7.95 indicating normal to slightly alkaline character. Electrical Conductivity (EC): The conductivity of natural water is between 50 to $1500 \mu \mathrm{S} / \mathrm{cm}$ (Toure et al., 2017). In the study area the $E C$ varies from as low as $0.23 \mu \mathrm{S} / \mathrm{cm}$ in the surface water of near Khetarpal ji temple (S4) to as high as 16.9 $\mu \mathrm{S} / \mathrm{cm}$ in the hand pump water of near main highway, Rawatsar (S9). A big difference is observed between the conductivity values of surface water and ground water.

Total Dissolved Soilds (TDS): The total dissolved solids of surface water ranged from a minimum of $161 \mathrm{mg} / \mathrm{l}$ of near khetarpal ji temple, Rawatsar (S5) to a maximum of $8330 \mathrm{mg} / \mathrm{l}$ daab (S1), Rawatsar. Similarly the 
variation of total dissolved solids of ground water ranged from a minimum of $525 \mathrm{mg} / \mathrm{l}$ of mainawali (S26) to a maximum of 11,830 $\mathrm{mg} / \mathrm{l}$ of near main highway, Rawatsar (S9). The total dissolved solids of tap water 217 $\mathrm{mg} / \mathrm{l}$ of $16 \mathrm{KWD}$ (S19) and $252 \mathrm{mg} / \mathrm{l}$ of Rawatsar (S22). TDS of rain water is $217 \mathrm{mg} / \mathrm{l}$ of mainawali (S27). Eleven samples are below the standard value. Highest TDS value is $11,830 \mathrm{mg} / \mathrm{l}$ of near main highway, rawatsar (S9). Their minimum values were recorded in $161 \mathrm{mg} / \mathrm{l}$ (S5) for surface water. Our findings are corroborated with Mahananda et al. (2010). Hence, TDS of water are composed mainly of carbonates, bicarbonates, chlorides, phosphates and nitrates of calcium, magnesium, sodium, potassium and manganese, organic matter, salt and other particles (Mahananda et al. 2010). Water with high dissolved solids may induce an unfavorable physiological reaction in the transient consumer and generally are of inferior palatability. The Indian Council of Medical Research (ICMR) has recommended $500 \mathrm{mg} / \mathrm{l}$ as acceptable and $1500 \mathrm{mg} / \mathrm{l}$ as maximum permissible limit of TDS (Maurya 2017).

Turbidity: Turbidity consists of suspended particles in the water and may be caused by a number of materials organic or inorganic. The standard maximum permissible limit for turbidity of tap water is 1 NTU. The samples studied for turbidity range between 0 NTU to 4.8 NTU. S1, S3, S7, S8, S9, S15, S18, S20, S26, S29 and S30 were found above the permissible limit and rest samples were below the permissible limit. The mean turbidity of the samples collected within the sampling period was all below the WHO for drinking water maximum permissible limit of 5 NTU. Hence, according to WHO, all samples are within permissible limit for turbidity. The occurrence of turbidity in surface water may be permanent or seasonal. Turbidity is an indication of the effectiveness of filtration and coagulation of water supplies.

Chloride: The presence of chlorides in natural waters can mainly be attributed to dissolution of salt deposits in the form of chloride ions $\left(\mathrm{Cl}^{-}\right)$. It is the major form of inorganic anions in water for aquatic life. The BIS has recommended $250 \mathrm{mg} / \mathrm{l}$ as acceptable limit of chloride. In the present study area, the lowest concentration of $\mathrm{Cl}^{-}$is of $71 \mathrm{mg} / \mathrm{l}$ (IGNP CANAL-S4) and maximum concentration is $30,530 \mathrm{mg} / \mathrm{l}$ (daab, rawatsarS1). Six samples (S4, S5, S20, S21, S22, S27) were found below the permissible limit and rest samples were above the permissible limit.

Alkalinity: Alkalinity indicates the levels of carbonate and hydroxyl groups in water although hydroxyl is uncommon in natural water. Alkalinity leads to corrosion and influences chemical and biochemical reactions in the water and also imparts bitter taste. The BIS standard for alkalinity is 200 $\mathrm{mg} / \mathrm{l}$ for drinking water. In the present study area, the lowest value of alkalinity is $40 \mathrm{mg} / \mathrm{l}$ (Gorkhnath ji temple, rawatsar-S10) and maximum value is $640 \mathrm{mg} / \mathrm{l}$ (Dhannasar-S23). Thirteen samples (S1, S2, S3, S5, S9, S10, S12, S19, S20, S22, S27, S29 and S39) were found below the permissible limit and rest samples were above the permissible limit. Most of the water samples have higher alkalinity showing presence of carbonates ions in water samples. 
Sodium and potassium: Sodium $(\mathrm{Na})$ varied widely between 1.35 to $365 \mathrm{mg} / \mathrm{l}$ in fresh water in the study area. $\mathrm{Na}$ is a dominant cation and varies from $1.35 \mathrm{mg} / \mathrm{l}$ of the sahwa lift canal (SW-S20), rawatsar (tap water-S22), mainawali (rain water collection$\mathrm{S} 27)$ to $365 \mathrm{mg} / \mathrm{l}$ in mishtri market, rawatsar (S3). The major source of sodium and potassium is weathering of rocks besides the sewage and industrial effluents. Potassium (K) in natural water comes from potash feldspars, micas and feldspathoids and evaporates. $\mathrm{K}$ ranges between $0.20 \mathrm{mg} / \mathrm{l}$ (Bawdi shivmandir$\mathrm{S} 2)$ to $10 \mathrm{mg} / \mathrm{l}$ (khodan-S21) in the study area. The study shows that $\mathrm{Na}$ and $\mathrm{K}$ are the dominant cation in the region.

Dissolved Oxygen (DO): Dissolved oxygen is very important parameter of water quality and an index of physical and biological process occurring in water. When temperature increases gas solubility of water decrease and microbial activity increase; both these changes can reduce DO in water. WHO standard specifies minimum value under the DO test as $5 \mathrm{mg} / \mathrm{l}$. The samples studied for dissolved oxygen range between 0 (S8-Sam water, Rawatsar) to $6.4 \mathrm{mg} / 1$ (S4-IGNP). Sample S8 is waste water and it showed nil dissolved oxygen.

COD: The chemical oxygen demand (COD) of the samples which gives the empirical values of the oxygen requirement for the oxidation of organic matter. The standard maximum permissible limit for COD water is $300 \mathrm{mg} / \mathrm{l}$. The samples studied for COD range between $24 \mathrm{mg} / \mathrm{l}$ (bawdi shivmandir, rawatsar-S2) to $163.2 \mathrm{mg} / \mathrm{l}$ (near bahra house, rawatsar-S7). Ten samples (S4, S5, S10, S12, S19, S20, S22, S27, S29 and
S30) were found below the permissible limit and rest samples were above the permissible limit.

\section{Conclusion}

From the present study, it was found that tap water is potable. However, chloride content in few tap water samples were above the permissible limit given by BIS. Surface water and ground water samples have higher turbidity and high content of total dissolved solids, alkalinity, chloride, sodium and potassium. Ground water have dominance of chloride, carbonate, sodium and potassium ions. Contamination of water resources need to be resolved by proper treatment. This is a preliminary study. So, further research is required to understand the hydrogeochemistry of ground water and chemistry of surface water in Rawatsar village.

\section{References}

Asare-Donkor NK, Boadu TA \& Adimado AA. 2016. Evaluation of groundwater and surface water quality and human risk assessment for trace metals in human settlements around the Bosomtwe Crater Lake in Ghana. SpringerPlus, 5: 1812.

BIS. 1991. Bureau of Indian Standard: Indian Standard Specifications for Drinking Water (IS: 10500-1991).

Choudhary P, Dagankar A \& Praveen S. 2007. Physiochemical analysis of groundwater for evaluation of drinking water quality at Dhār, M.P. National Environmental and Pollution Technology, 6 (1): 109112.

Gandhi VP \& Namboodiri NV. 2009. Groundwater Irrigation in India: Gains, costs and risks. Indian Institute of Management, Ahmedabad, India. 
Retrieved

from:

https://web.iima.ac.in/assets/snippets/wo rkingpaperpdf/2009-03-08Gandhi.pdf

Ground water scenario Hanumangarh, Rajasthan. 2013. Central ground water board. Retrieved from: http://cgwb.gov.in/District_Profile/Rajas than/Hanumangarh.pdf

Hydrogeological Atlas of Rajasthan Hanumangarh District. 2013. Ground water department, Rajasthan. Retrieved from:

https://phedwater.rajasthan.gov.in/conte nt/dam/doitassets/water/Ground\%20Wat er/Pdf/

PublicReports/Groundwater_Atlas/Distri cts/Districtwise\%20Atlas\%20-

$\% 20$ Hanumangarh.pdf

Jha MK, Shekhar A \& Jenifer MA. 2020. Assessing groundwater quality for drinking water supply using hybrid fuzzy-GIS-based water quality index. Water Research, 179: 115867.

Kumar D, Choure K, Gurnani C, Kumar V \& Mukhija S. 2016. Physicochemical analysis of drinking water in Hanumangarh District,Rajasthan India. International Journal of Emerging Trends in Science and Technology, 3 (10): 4685-4694.

Lawrence E. 2017. Comparative quality analysis between surface water and groundwater. A case study of Otamiri river and water boreholes in owerri west, Imo State Nigeria. International Journal of Advanced Technology and Engineering Exploration, 4 (36): 168175.
Mahananda MR, Mohanty BP \& Behera NR. 2010. Physico-chemical analysis of ground and surface water. International Journal of Recent Research and Applied Studies, 2 (3): 284-295.

Maiti SK. 2011. Handbook of methods in Environmental studies: vol.1: water and waste water analysis. ABD Publishers, Jaipur pp. 1-296.

Maurya A. 2017. Assessment of Hydrogeochemical parameter of ground water at Rawatsar tehsil Hanumangarh district, Rajasthan. International journal of engineering research and technology, 6 (3): 484-487.

Midha R, Dhingra A \& Malhotra G.2016.Physico-chemical characterization of Indira Gandhi canal, Sri Ganganagar (Rajasthan).International Journal for Environmental Rehabilitation and Conservation, 7 (1): 26-35.

Olasoji SO, Oyewole, NO, Bayode A \& Edokpayi, JN. 2019. Water quality assessment of surface and groundwater sources using a water quality index method: A case study of a peri-urban town in Southwest, Nigeria. Environments 6: $23 . \quad$ doi: https://doi.org/10.3390/environments602 0023

Sankar MV, Abideen S, Selvam MB, Gunasekaran T \& Bava MIHS. 2014. A comparative study of ground water by physico chemical parameter and water quality in the lalguditaluk of angaripancyayat of tiruchirappalli district tamilnadu, India. International 
Journal of Science, Environment and Technology, 3 (1):3 48-356.

Sharma S. 2011. Ground water quality appraisal in chhibramau block Kanauji district of Utter Pradesh. Annals of Plant and Soil Research, 13: 71-72.

Singh AK, Qadar A, Yadvansh NPS. 2009. Mineral nutrition of crop plants in salt affected areas in India. ICAR, New Delhi, CSSRI, Karnal. Retrieved from:

Singh G, Singh D \& Sharma S. 2013. Effect of polluted surface water on groundwater. A case study of Budha Nullah. IOSR Journal of Mechanical and Civil Engineering, 5 (5): 1-8.

Tiwari AK, Singh AK, Singh AK \& Singh MP. 2017. Hydrogeochemical analysis and evaluation of surface water quality of Pratapgarh district, Uttar Pradesh, India. Applied Water Science, 7: 16091623.

Toure A, Wenbiao D \& Keita Z. 2017. Comparative study of the physicochemical quality of water from wells, boreholes and rivers consumed in the commune of pelengana of the region of segou in Mali. Environmental Science Indian Journal, 13 (6): 1-13.

Verma P, Singh PK, Sinha RR \& Tiwari AK. 2020. Assessment of groundwater quality status by using water quality index (WQI) and geographic information system (GIS) approaches: a case study of the Bokaro district, India. Applied Water Science, 10: 27. 